\title{
RushdiE's Wo/MANICHEAN Novel
}

\section{Peter Nazareth}

"Make no mistake," he said in that court, "we are here to change things. I concede at once that we shall ourselves be changed; African, Caribbean, Indian, Pakistani, Bangladeshi, Cypriot, Chinese, we are other than what we would have been if we had not crossed the oceans, if our mothers and fathers had not crossed the skies in search of work and dignity and a better life for their children. We have been made again: but I say that we shall also be the ones to remake this society, to shape it from the bottom to the top. We shall be the hewers of the dead wood and the gardeners of the new. It is our turn now." (114)

The words belong to Sylvester Roberts, a/k/a Dr. Uhuru Simba, as presented by his mother at a rally after his death in police custody. He had been arrested for being the Granny Ripper and had died, the police said, by falling off his bunk while having a nightmare, died before the real Granny Ripper was caught. The action is taking place in London, the center of the Empire. This scene reveals some of Rushdie's central concerns in The Satanic Verses. We see brutal racism at the heart of the Empire under the cover of British liberalism. Colonials gather at the mother country and meet one another, as they do in Sam Selvon's London novels such as Moses Ascending (London: Davis-Poynter, 1975), one of the many works I feel has been digested by Rushdie's novel (he says in his Acknowledgements, "The identities of many of the authors from whom I've learned will, I hope, be clear from the text"). The colonials are out to change the mother country and in the process change themselves.

Rushdie's novel, then, has a radical political purpose: he intends to reverse European, and specifically, British imperialism through his novel. One of the ways in which the colonizers controlled the colonials was by imposing their language on the people; as Frantz Fanon said, those who control language control reality. So Rushdie turns the tables by presenting, and writing in, the English language as used by various colonized peoples. Thus we find in his novel Indian and West Indian English, in ad- 
dition to various English dialects. One of the two protagonists, Saladin Chamcha, is literally a man of a thousand voices: he uses them on commercials and on T.V. shows. Moses says/writes in Moses Ascending: "As how yam and saltfish become part of the English scene with the coming of the blacks, so hundreds of little Indian shops have opened up all over the metropolis, and the Englishman no longer has to risk a perilous voyage to obtain the spices of the East; they are right here in the high street" (59). Some time ago, Rushdie published an article entitled "The Empire Writes Back with a Vengeance" (The Times, July 3, 1982, 8).

Given the uproar over the question of blasphemy, we might miss the political radicalism of the novel, and lest we do, Rushdie quotes Fanon twice on page 353 , as follows:

He [Gibreel] would show them-yes! - his power. - These powerless English! - Did they not think their history would return to haunt them? - 'The native is an oppressed person whose permanent dream is to become the persecutor' (Fanon). English women no longer bound him; the conspiracy stood exposed! - Then away with all fogs. He would make this land anew. He was the Archangel, Gibreel. - And I'm back!

The fact of the adversary hung before him once again, sharpening, clarifying. Moony with a sardonic curl to the lips: but the name still eluded ... tcha, like tea? Shah, a king? Or like a (royal? tea?) dance: Shatchacha. - Nearly there. - And the nature of the adversary: selfhating, constructing a false ego, auto-destructive. Fanon again: 'In this the individual' - the Fanonian native - 'accepts disintegration ordained by God, bows down before the settler his lot, and by a kind of interior restabilization acquires a stony calm.' - I'll give him stony calm! - Native and settler, that old dispute, continuing now upon these soggy streets, with reversed categories. - It occurred to him now that he was forever joined to the adversary . . .

The text seeks to break the colonial relationship. Thus it breaks up linguistic forms. Thus too the use of the offensive, medieval "Mahound": when Gibreel Farishta begins to have his strange dreams: "Here he is neither 'Mahomet nor MoeHammered: has adopted, instead, the demon-tag the farnagis hung around his neck. To turn insults into strengths, whigs, 
tories, blacks all chose to wear with pride the names they were given in scorn; likewise, our mountain-climbing, prophet-motivated solitary is to be the medieval baby-frightener, the Devil's synonym: Mahound" (93). In other words, the Muhammad figure, by taking on, in Farishta's dream, the name imposed on him by medieval Christians, reverses the process of colonizing and exploiting the non-West.

But Rushdie's method is broader than that of the 1960s followers of Fanon. (Fanon's The Wretched of the Earth and Black Skin, White Masks are classic explorations of the colonizer/colonized relationship.) Third World radicals of the sixties were rejectionist. Rushdie embraces, creating a literary gumbo. One can find various writers in his gumbo, e.g. Ishmael Reed: "The Imam is the enemy of images. When he moved in the pictures slid noiselessly from the walls and slunk from the room, removing themselves from the rage of his unspoken disapproval" (206). The gumbo includes everything because in the modern world, thanks largely to the media, the consciousness of the colonials includes heterogeneous elements. Note the lines quoted on page 442 from Cliff Richard's first no. 1 hit in England, "Living Doll," number 1 in 1959 and number 1 again in 1987, backed by The Young Ones, a T.V. group inspired by a movie starring Richard and his next top single. Why Cliff Richard, the first real rock ' $n$ ' roller of England, a star who continues to have number 1 hits? Because like his parents, Cliff Richard was born in India - as Harry Webb, later renaming himself after Little Richard. The Webbs left for England shortly after Independence, just after Rushdie was born, because of anti-English sentiment. At school in England, "his skin was so dark-tanned after all his years in India that the other children would shout out 'nigger' and 'where's your head-dress' thinking that India was the home of cowboys and Indians!" (George Tremlett, The Cliff Richard Story, London: Future Publications, 1975, 18). Harry Webb the alien, the immigrant, had to create a new identity, using something that came from across the ocean: black music. We can see here the power of the media in helping one create a new self.

Thus Rushdie's novel, like novels by Reed, is dominated by references to, and forms from movies, T.V., comics, and so on. The protagonists, Gibreel Farishta and Saladin Chamcha, have not only given themselves their names: they are stars on the media, the former acting as Hindu gods in Indian movies and the latter doing voices on English T.V. Their percep- 
tion of the world is completely influenced by the media, as indeed are people's perceptions of them. The sections of the novel that have offended many Muslims as blasphemous are presented as though they are dreams of movies because that is how Farishta sees life. Several episodes are like scenes from movies. For example, the scene when the Imam gets a ride on Gibreel and has a battle to the death with Ayesha, who turns out to be AlLat, is just like the climactic scene in Ghostbusters. The long description of London burning is just like the scene in Sammy and Rosie Get Laid, a movie for which the London-born Hanif Kureshi wrote the script (Rushdie uses both names in his novel, as "Hanif Johnson" and "Mrs. Qureishi"). Rushdie even permits himself some in-jokes from Indian movies. The doomed flight number is 420 , and this, taken from an Indian movie, means something like "rascal."

How does Islamic culture fit into this scenario? Does it blend into the gumbo? The answer is yes because so much from Islamic culture has become part of the Western world. Thus references are made in the novel to Sesame Street - where did "sesame" come from? - and to Sinbad the sailor and to the genie and the magic lamp and to the magic carpet. Apulius, we are told on page 243, was a Moroccan: and the fictional blending of fantasy and reality of this novel is first found in the classic Arabian Nights (342).

Rushdie is attemping to break out of a manichean world, the world of the good guys versus the bad guys, a world analyzed in literary terms by Abdul R. JanMohamed in his Manichean Aesthetics (Amherst: University of Massachusetts Press, 1983). We are presented with a manichean world when the novel opens: as Gibreel Farishta and Saladin Chamcha fall from the blown-up plane, the former, in keeping with his name, seems to become the Angel Gabriel and the latter takes on satanic attributes, becoming goat-like and growing horns. Yet we know from the detailed description of things falling from the plane with them that the world is multiple. Chamcha had fled from India to the colonial heaven when he was a teenager, seeking to embrace Englishness, refusing to see that, as his Indian lover Zeeny Vakil tells him, the English do not want his dark skin, they only want his unseen voices. His marriage to Pamela Lovelace is a concrete manifestation of his desire to embrace the colonizer (see Fanon's Black Skin, White Masks). He has even changed his name from Salahuddin to Saladin, a name from stories of the Crusades the English admire because 
they saw Saladin as a noble adversary, the lone good guy from the other side. Zeeny shortens his name to "Salah," an "abusive" term in India, while Farishta calls him "Salad," a mixed dish. The name also brings to mind Tayeb Salih, the Sudanese novelist who wrote the famous Season of Migration to the North (translated by Denys Johnson-Davies, London: Heinemann, 1969). In contrast to Saladin, Farishta has rejected everything about England, until he suddenly follows to England a white woman mountain climber he loves, Allie Cone, who is actually of Polish-Jewish origin. Saladin is to experience rejection in England while Gibreel will experience the opposite.

Is it true that the angel and Satan are opposite characters, the good guy with the white hat and the bad guy with the black? Or are they dual possibilities within the same person and nation? Out of revenge, Saladin coldly uses his many voices to destroy the relationship between Gibreel and Allie. But must harm be returned for harm? Gibreel finds out what Saladin has done while London is burning. The novel has echoes of T. S. Eliot. After such knowledge what forgiveness? The novel answers that there can be forgiveness. Gibreel-as the Angel Azraeel-saves Saladin. Saladin goes back to India, despite his understandable fear of flying, because his father, with whom he is very angry, is dying. The scene of forgiveness is perhaps the most moving one in the novel: one wishes those who have condemned Rushdie to death could be equally forgiving. On a vaster scale, Gibreel Farishta, as the Angel Gibreel, has come to London not to destroy it but to save it: "He would redeem this city: Geographer's London, all the way from A to Z."

Was manicheanism rammed down the throats of the colonized by the the European colonizers? Or did the colonized pave the way by adopting a kind of one-sidedness that weakened them? This is the question raised through the historical, or apocryphal, "Satanic Verses." When Muhammad brought his message of one God, the God, a compromise was proposed to him: that he accept three goddesses, one of them being Al-Lat. Supposedly he first accepted the compromise, but later rejected those verses as being inspired by Satan. With this rejection, the feminine element so important in human balance was lost. Thus women play a very important part in the novel in helping people find balance. One of the important women is Ayesha, a latter-day prophet in a small Muslim village in India, who leads the whole village on a pilgrimage to Mecca. She says the 
Arabian Sea will part when they get to it. The sceptics who were originally believers and who come out of the Sea all tell the police that the Sea did part so that the pilgrims could walk to Mecca: the only one who did not see the Sea part is the Muslim unbeliever Mirza Saeed. (This chapter alone should undermine the idea that Rushdie's novel is anti-Islamic.) The male characters are unbalanced when they do not pay attention to the female element. Thus when Gibreel is about to be reintroduced to the audience in England as having survived the plane disaster, he has to be disguised as follows: "Gibreel had to enter the Earls Court stage-door dressed in a burqa. So even his sex remained a mystery" (350).

The chapters that have been hurtful to Muslims must be seen in their literary context. The "blasphemous" scenes are the dreams of Gibreel Farishta. Is he schizophrenic? Is he a split personality because of the gap between a great Islamic culture and the reality of being despised colonials in the Christian colonial center? He has to take medication, but much later, it seems the medication did not help and back in India, he is responsible for the death of the film producer Sisodia and of his lover Allie Cone. He commits suicide in the house of Salahuddin as the police are closing in. How did he start having his "blasphemous" dreams? He was a staunch believer. When he recovered after a sudden collapse and near-death, he felt that Allah had not listened to his prayers. He became an unbeliever, eating pork, challenging God. Then he began having the dreams. The dreams, as text, were created by God, by author as God and God as author: see pages $133,408,229,297,304,311,315,320,397-8,435$, and 525 . We must examine the text through which we receive our messages of the world. This is emphasized by the exchange between Salman, the scribe who has been tampering with Mahound's messages, and Mahound: "Your blasphemy, Salman, can't be forgiven," says Mahound. "Did you think I wouldn't work it out? To set your words against the Words of God" (374). In other words, this text we are reading is not to be taken as the word of God. PaPa LaBas in Ishmael Reed's The Last Days of Louisiana Red (New York: Random House, 1974) realizes a verse in "Minnie the Moocher" has been tampered with: if he can find out what the verse was, he can find out what he wants to know. This idea is emphasized on page 392 of Rushdie's novel when the poet Baal is about to be beheaded:

"Whores and writers, Mahound. We are the people you can't forgive."

Mahound replied, "Writers and whores. I see no difference here." 
In seeking to break out of a manichean world, Rushdie constantly stresses the possibility of change. Everyone changes or gets a chance to be born again. Saladin marvels, "O, the conflicting selves jostling and joggling within these bags of skin" (519). When his father is dying, "Saladin felt hourly closer to many old, rejected selves, many alternative Saladins or rather Salahuddins - which had split off from himself as he made his various life choices, but which had apparently continued to exist, perhaps in the parallel universes of quantum theory" (523). It should be no surprise that the novel has two characters named Hind and several Ayeshas.

Why is the possibility of change so important? Because everyone is haunted. Everyone sees ghosts: the ghost of history past is there right now: London is haunted both by the people who conquered England and by the people England conquered. If we do not change, we could all selfdestruct. The immigrant need not be an alien trying to fit in: $s /$ he can be the person who does not play by the rules. $\mathrm{S} / \mathrm{he}$ can be the person who provides a different way of seeing the world. But such a way of seeing the world can only come out of an embrace, not from keeping the alien world out. It might be true that the T.V. camera can be used to reinforce colonial myths because it does not see everything (454), and it might also be true that we live in a fast-forward culture (402). But movies influence the way we see the world, and gods, and history, and so we must pay attention to the messages and the media, not block them out. Ayesha admits she receives her messages from Gibreel to the tune of pop songs. The writer from the colonized world who gets into the Western world is not doomed to be a Western agent, that is a modern-day factor, the person who was responsible for selling his people into slavery but who could not be seen by them. This is the fear of Modin, a Ghanaian at Harvard in Ayi Kwei Armah's Why Are We So Blest? (New York: Doubleday, 1972). Modin's solution is to be like Prometheus, to bring back the fire from the city-state: that is, to bring back the text. Rushdie has also performed the Promethean feat: he has brought back a multi-text. 